\title{
NASA relativity probe facing costly delay
}

\section{Washington}

A controversial project by the US space agency NASA to test Einstein's general theory of relativity in Earth orbit has run into a technical snag that is likely to increase costs and delay its launch. Some $\$ 21$ million or more could be added to the $\$ 535$ million price tag, and the launch - originally planned for next October - could be put back by several months at least.

Project managers at Stanford University in California believe that thermal problems with the Gravity Probe B (GPB) spacecraft should be relatively easy to fix, but the uncertainty is worrying NASA science officials. "We're colouring it red," says Alan Bunner, who heads the agency's programme on the structure and evolution of the Universe.

GPB, also known as the Relativity Mission, will try to measure precisely the 'frame dragging' effect, whereby a massive rotating body such as the Earth is thought to drag space and time along with it as it turns. The effect is expected to show up as a slight deviation in the alignment of four exquisitely sensitive gyroscopes spinning inside a supercooled helium dewar.

During recent ground tests, however, engineers discovered that heat is not being conducted out from the interior of the spacecraft as it should. If the problem were left unfixed, cryogenic helium in the thermoslike dewar would boil off in orbit within a few months, ending the 16-month mission prematurely.

The culprit appears to be an epoxy resin that has come unbonded from a titanium liner inside the probe, severing an important pathway for conducting heat. Stanford engineering professor Brad Parkinson, one of three co-investigators for GPB, says "the probability is 98 per cent that this is the problem," and that "we can easily see a solution" - adding copper pins and epoxy to restore the thermal pathway.

But this requires removing the probe from the dewar. This would delay the launch from next October to at least May 2001, and probably later if an additional margin is built into the schedule as the Stanford team would like. NASA expects to decide the new launch date this month.

First conceived at Stanford University in 1959, GPB has already had a long and turbulent history. NASA commissioned the first mission study in the mid-1960s, and began funding substantive work on the project in the mid-1980s.

Often criticized as a technologically risky experiment with little support from the wider scientific community, GPB has been threatened with cancellation several times. The most recent hurdle was a make-orbreak 1995 recommendation to NASA by a

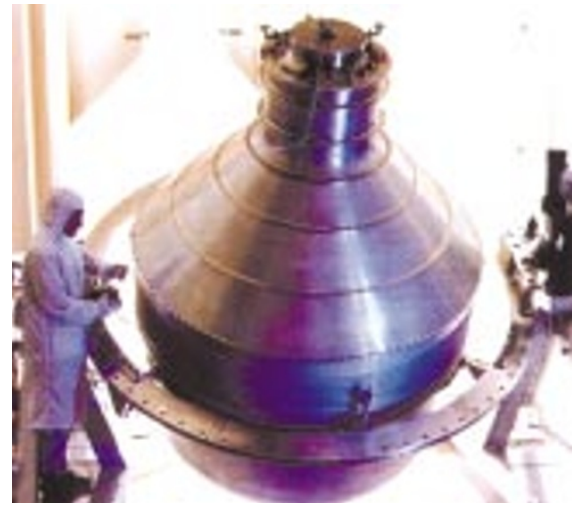

Getting warm: the dewar housing the gyroscopes may lose its cryogenic helium too quickly.

National Research Council committee that the project should continue.

But the committee was deeply divided as to GPB's merit compared with other space projects. And it cautioned that a surprising result - Einstein shown to be wrong would probably not be accepted without a repeat mission. NASA has no plans to fly a follow-up mission.

Parkinson says GPB is a target for criticism because fundamental physics “doesn't appear to have a major constituency" at NASA. And he defends the project's four- to six-per-cent budget overrun as not unusual, especially given the advanced technology that had to be developed. This includes extremely precise pointing and manoeuvring and the use of a 'drag-free' orbit.
But the project has overspent its budget by $\$ 20$ million in the past two years, says Bunner, which has raised the level of concern at NASA headquarters. An earlier launch delay from March to October 2000 prompted the agency to add oversight staff at Stanford. Parkinson counters that the $\$ 20$ million had actually been taken from programme reserves in previous budget years and was never restored.

And he says the new launch delay, if approved, will allow other minor problems to be fixed, including one that would have made one of the four gyroscopes unusable.

At another time, a \$21 million overrun might not have made a dent in NASA's budget. But the problem comes at a bad time for the agency's science office, which is struggling to contain costs in other areas, including its Mars exploration programme.

Ed Weiler, head of NASA's space science, decided last summer to cancel the Champollion comet mission, in part because of budget pressures caused by expensive delays with the Chandra X-ray observatory (see Nature 400, 99; 1999). The Congress also recently earmarked more than $\$ 70$ million worth of pet projects to be taken out of the general science budget in the coming year.

Congress also gave Weiler a $\$ 10$ million increase in the 'fundamental physics' account. Instead of funding new missions, the money is likely to cover the latest delay with GPB, the longest-running development project in NASA's history. Tony Reichhardt

\section{Threats to US primate researchers}

Boston

A radical animal rights group calling itself the Justice Department last week mailed threatening letters, with razor blades dangerously positioned inside the envelopes, to scientists at primate research centres across the United States.

The letters, which were sent from Las Vegas, Nevada, with no return address, told the researchers: "You have until autumn of 2000 to release all your primate captives," and added "if you do not heed our warning, your violence will be turned back upon you".

The group's website includes a list of 83 scientists who had been targeted. Letters have turned up at the universities of Harvard, Emory, Tulane, California, Michigan, Minnesota, Oregon and Wisconsin, but no injuries have been reported.

The universities had already been contacted by the Foundation for Biomedical Research, a non-profit organization in Washington that endorses animal research and monitors the websites of extremist groups.

"The scientific community is not prepared for these kinds of terrorists acts, so we're doing anything we can to protect them," said the foundation's president, Frankie Trull. "Until recently, there had been a sense of complacency regarding animal rights activists, but this incident should help scientists realize the threat to their personal safety and to their ability to conduct research."

The threats are being taken seriously by the universities. The letters have been submitted to the Federal Bureau of Investigation, which is handling the case, and university officials are calling for extra vigilance and, in some cases, heightened security measures.

Protests at Harvard's primate research centre in Southborough, Massachusetts, over the past two summers had already prompted the installation of additional surveillance equipment. 


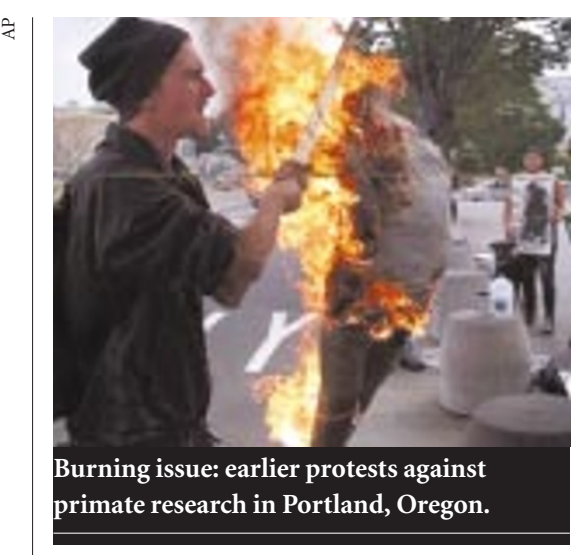

"This is an escalation of what has happened in the past, but fortunately no one was hurt," said Don Gibbons, a spokesperson for Harvard Medical School, which last week received eight letters from the Justice Department.

Meanwhile, extra security guards have been stationed at the facility. Rocks were thrown at a security guard's car during a routine patrol last Thursday, but officials cannot link the incident to the threatening letters.

The Justice Department has not targeted US researchers before, although it has been active in Britain and Canada. Five years ago, it sent letter bombs to European companies, and two years later sent letters containing razor blades to hunting guides and furriers in Canada.

The best-known extremist group, the Animal Liberation Front, has said it was responsible for fire-bombing four vans belonging to a Rhode Island furrier two weeks ago. The group also claimed responsibility for a break-in at a Western Washington University laboratory two days later. Offices were ransacked and several dozen laboratory animals stolen.

"Acts of violence appear to be on the increase," says Trull. Along with others who support the use of animals in medical research, she fears that activists are resorting to the same intimidation tactics used by anti-abortion extremists.

Andrew Rowan, senior vice-president of the Humane Society of the United States, says he is "unalterably opposed to these tactics. Threatening violence is contrary to the basic tenets of the animal protection movement, which is aimed at protecting all animals, including humans."

Trull says that, although catching those who sent the letters is a job for lawenforcement agencies, scientists have a part to play. "The scientific community has to explain to the public why animal research is necessary," she says. "Very few medical advances made this century did not depend, at least in part, on animal research, and that's not likely to change in the near future." Steve Nadis

\section{French scientists resign from Allègre's advisory council}

\section{Paris}

Two prominent French scientists have resigned from the National Science Council (CNS), a special advisory panel created by the science minister, arguing that it is consulted on major decisions only after they have already been taken by the ministry.

In a move seen as a direct criticism of the leadership style of science minister Claude Allègre, mathematician Yves Meyer and Nobel-prizewinning physicist Claude Cohen-Tannoudji delivered their letters of resignation to Allègre and the prime minister, Lionel Jospin, on 14 October.

"According to [earlier comments by] the national minister for education, research and technology, researchers should return to work in their labs rather than waste time on ineffective committees," wrote Meyer. "That is what I propose to do."

Allègre set up the council in October last year to advise him on large-scale projects and research strategy. The move followed the creation of a fund controlled by the ministry, known as the National Science Funds, to be spent on reforms and major projects. This year, it increased to FF565 million (US\$91 million) for the year 2000 budget (see Nature 401,313; 1999).

But instead of advising the minister on important decisions, says Cohen-Tannoudji, the council met only three times, and on each occasion listened to reports from the minister on policies or reforms that he had already instituted. "It was more like a briefing session," he says.

According to Meyer, the last straw came when the minister was quoted in the newspaper Le Monde as saying that the council backed Allègre's decision to go along with British plans to build a new synchrotron two weeks before the council discussed the subject (see Nature 400, 489; 1999).

The decision was taken in preference to plans to build a French machine that had been 10 years in the making. When the issue of the synchrotron was raised at a CNS meeting on 1 October, it met with strong disap-

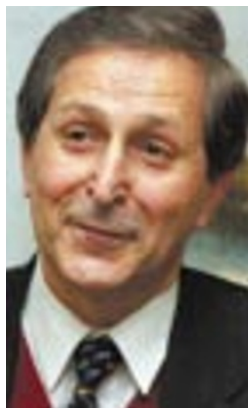

Cohen-Tannoudji: won't waste his time on 'ineffective' body. proval from most council members, according to those present at the meeting.

Vincent Courtillot, director of research at the ministry and Allègre's main adviser, says many decisions taken by the government have been approved by most council members. "Members are free to express their views in the CNS, as was widely done at the 1 October meeting," he says. "The debates may end with majority and minority views on advice to the government." Heather McCabe

\section{Japan plans ethics guidelines}

Tokyo

Japan's Ministry of Health and Welfare announced plans last week to set up the country's first ethical guidelines for the management and use of human genetic information for biomedical research.

As an initial step in this direction, the ministry has created an ad hoc working group to address ethical issues on research using human DNA samples, including the protection of personal genetic data, and to discuss measures for obtaining adequate informed consent from patients giving samples.

The working group, whose members include directors of national medical institutes, academics and lawyers, plans to draw up draft guidelines by January. These would be made public as part of the ministry's plan to gather wide opinion from the general public which it intends to incorporate in the final guidelines to be compiled in March 2000.

The move reflects growing concern among researchers over the potential misuse of genetic information, which, the ministry says, "could not only violate privacy, but also lead to job and insurance discrimination".

The launch of projects related to the human genome - such as the planned database of single-nucleotide polymorphisms (SNPs), or sequence variations that could be linked to common diseases such as cancer and mental illness - have raised concerns over the confidentiality of research records.

Researchers involved in the SNP programme, which involves collecting a vast number of DNA samples from medical institutions across Japan, have insisted that samples be anonymous to avoid concerns over linked or identifiable samples.

According to the ministry, methods to ensure the anonymity of DNA samples, such as creating codes to identify them, will be the main priority of discussions to be held by the working group.
Asako Saegusa 